trated these common features in his own style. We do not suggest that the examples of de Chirico's work discussed here are illustrations of his migraine attacks as are those from the national migraine art competition. Rather, we propose that de Chirico used his experiences of classical migraine as one of the sources of inspiration for his paintings.

\section{Hallucinatory inspiration}

Visual migrainous hallucinations have provided inspiration for others. Charles Dodgson, better known as Lewis Carroll, is known to have suffered from migraine and is thought to have used his migrainous disturbances of body image as inspiration for Alice's Adventures in Wonderland..$^{10}$ Atkinson and Appenzeller described a patient who had migraine who painted her complex visual hallucinations." Hildegard of Bingen (1098-1180), a nun and mystic, had countless visions that she not only described but also illustrated. Her migraine "visions" have been reviewed by Singer ${ }^{12}$ and Sacks. ${ }^{7}$ It is of interest in our context that she thought that the visions were of divine origin, as de Chirico too seemed to interpret his as privileged revelations of another reality.

The symptoms acknowledged by de Chirico, taken with the evidence from his writings and confirmed by independent contemporary comments, suggest that he suffered from migrainous visual hallucinations. The evidence from some of his prints and paintings, when they are compared with those of other migraineurs, suggests that de Chirico used these hallucinations as a source for some of the more striking details of his work.

We thank Mr Derek Robinson of Boehringer Ingelheim for allowing us to see entries to the national migraine art competition and to use figures 2 and 5 . 1 De Chirico G. Memoirs (translated by M Crosland). London: Peter Owen,
1971.

2 Lanzi G, Balottin U, Ottolini A, Rosano FB, Fazzi E, Arisi D. Cyclic vomiting and recurrent abdominal pains as migraine and epileptic equivalents. Cephalalgia 1983;3:115-8.

3 De Chirico G. Hebdomeros (translated by M Crosland). London: Peter Owen, 1964.

4 Wilkinson M. Clinical features of migraine. In: Vinken PJ, Bruyn GW, Klawans HI, Rose FC, eds. Handbook of clinical neurology. Vol 4(48). Klawans HI, Rose FC, eds. Handbook of

5 Fisher CM. Late-life migraine accompaniments as a cause of unexplained transient ischaemic attacks. Can J Neurol Sci 1980;7-9,17.

6 Rose FC. Headache: definition and classification. In: Vinken PJ, Bruyn GW,

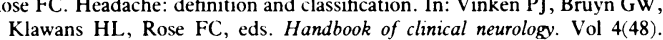
Headache. Amsterdam: Elsevier, 1986:1-12.

7 Sacks O. Migraine, evolution of a common disorder. London: Pan, 1981.

8 Breton A. Genesis and perspective of surrealism in the plastic arts. In Rosemont F, ed. What is surrealism? Selected writings of André Breton. London: Pluto, 1978:217-30.

9 Wilkinson M, Robinson D. Migraine art. Cephalalgia 1985;5:151-7.

10 Todd J. The syndrome of Alice in Wonderland. Can Med Assoc $\mathcal{F}$ 1955;73: 701-6.

11 Atkinson RA, Appenzeller O. Deer woman. Headache 1978;17:229-32.

12 Singer $C$. The visions of Hildegard of Bingen. In: From magic to science London: Ernest Benn, 1928:199-239.

\title{
The exhumation of Mattia Preti, painter
}

\author{
Victor G Griffiths
}

The Conventual Church of St John in Valetta, Malta, is widely regarded as one of the most precious examples of baroque art in southern Europe. It embodies the monastic element in the triple constitution of the Military and Hospitalier Order of St John of Jerusalem, the other elements of which are represented by the massive fortifications of Valetta itself and by the remains of the renowned Holy Infirmary standing at the tip of the peninsula overlooking the entrance to the Grand Harbour.

Of the artistic treasures in St John's church, the two that immediately attract the eye are the magnificent series of fresco paintings covering the colossal barrel vault of the church and the multicoloured series of 400 richly inlaid marble tombstones that cover the entire floor of the nave. The paintings are the work of Mattia Preti, and one of the tombstones covers his remains.

Mattia Preti was not the first nor the greatest Italian painter to adorn St John's. The superior genius of Caravaggio in the turbulent last years of his brief life had in 1608 left there two of his greatest masterpieces, the "Beheading of the Baptist" and a "St Jerome." After a period of relative obscurity Preti has risen in the estimation of art critics and art buyers to an exalted position as an exponent of seventeenth century baroque painting. In terms of magnitude and extent alone his singular embellishment of St John's, coupled with scores of other great paintings in various Maltese churches, renders him unrivalled as a contributor to the island's artistic heritage.

Born in 1613 to a noble family of Taverna in Calabria (hence his widely used appellation of "Il Calabrese"), Mattia Preti served his artistic apprenticeship in Naples and Rome, where Caravaggio's example and influence could inspire him. Among his mentors and exemplars are counted Guercino, Guido Reni, and Domenichino, and his travels to Florence, Venice,
Paris, and The Netherlands enabled him to study some of the best works of Luca Giordano, the Caracci, Veronese, Titian, Tintoretto, and Rubens. Many critics judge Preti to be almost worthy of being mentioned in the same breath as these great masters.

In 1659 Preti's noble origins enabled his acceptance into the Order of St John of Jerusalem as a Knight of Grace in the Langue of Italy and thus to offer his artistic services to the Order. Here is an interesting parallel and yet a contrast with Caravaggio, whom the Order rewarded with a Knighthood of Obedience for his great works for St John's, and mere months later imprisoned, unfrocked, and expelled "tamquam membrum putridum et foetidum" because of his serious misdemeanours.

The Grand Council of the Order in Malta under Grand Master Lascaris and his successors De Redin and Raphael Cottoner gratefully accepted Preti's offer to decorate the church of St John without charge at his own expense, and he started his work in October 1661. $\mathrm{Up}$ to that time the interior of the great church, the building of which dated from 1573, just seven years after the founding of Valetta, must have been as forbiddingly austere as its fortress like exterior. Preti's genius was to cover it with an exuberant riot of colourful ornamentation.

\section{Mattia Preti and St John's church}

He first designed structural alterations by adding and enlarging windows and widening arches and aisles, and contributed elaborate carvings and sculptures. Then from 1662 to 1666 he was totally occupied by the marvellous transformation of the barrel vault with his fresco paintings, although this medium was not as congenial to him as oils on canvas. $\mathrm{He}$ is said to have ingeniously used the porous character of Maltese of Malta, Guardamangia,

Malta

Victor G Griffiths, FRCs, head of department of surgery 
FIG 1-Tombstone of Mattia Preti in St John's church, Valetta, Malta

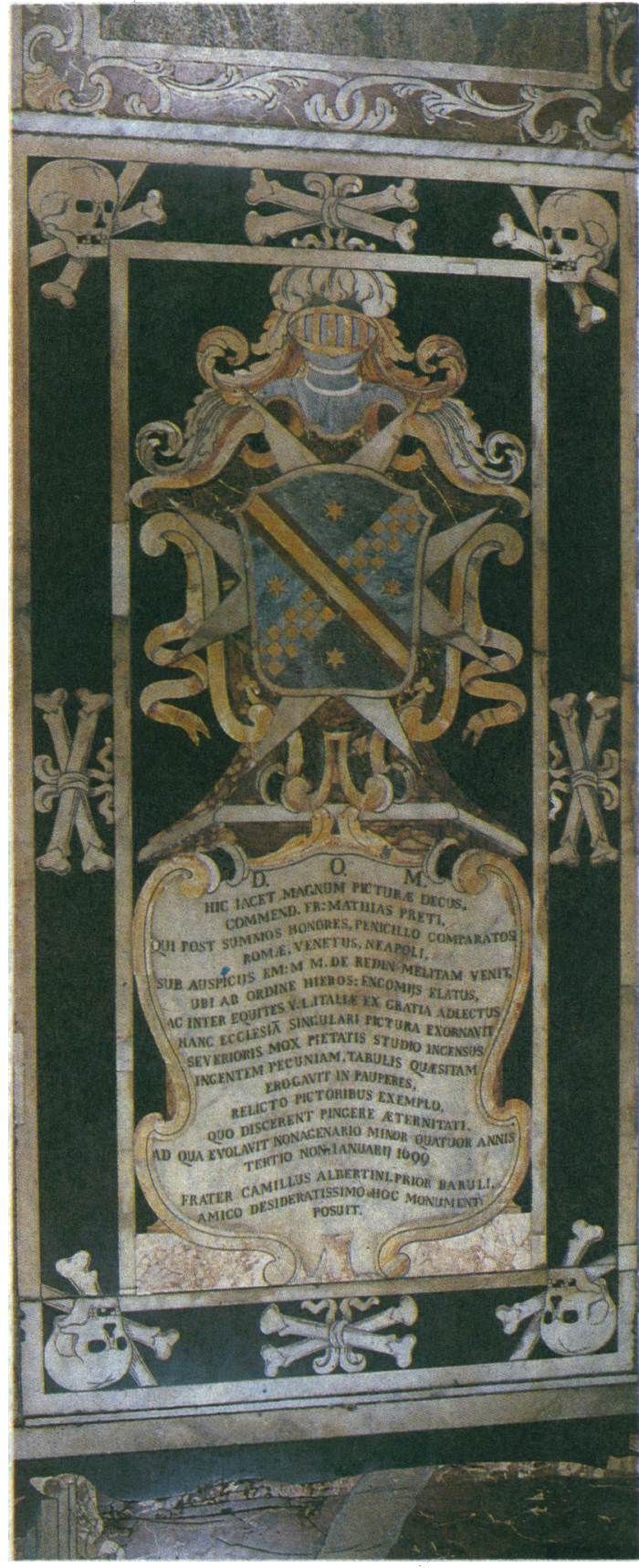

FIG 2-Exhumation of the remains of Mattia Preti

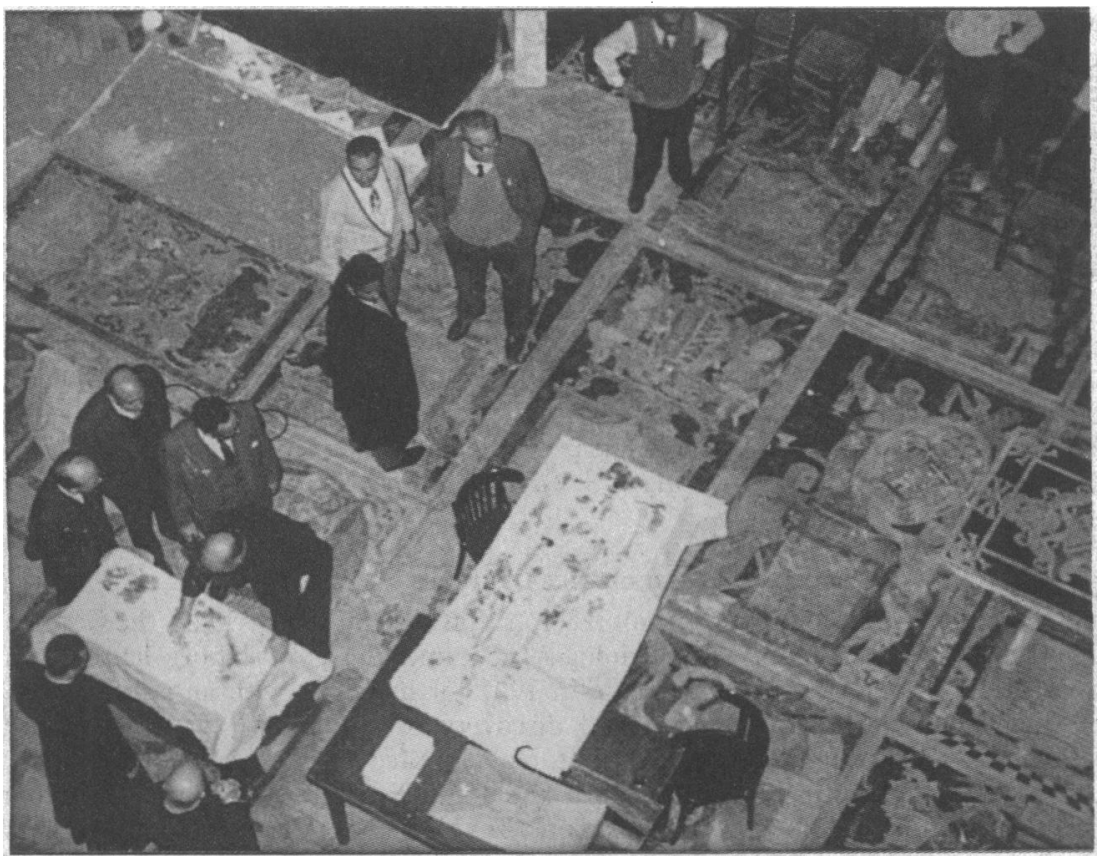

limestone by first sponging it with linseed oil, then applying the paint directly.

The subjects for Preti's frescos were supplied by 18 episodes from the life of St John the Baptist, together with a great allegory of the Order over the main entrance. To flank the high windows he painted a series of saints and heroes of the Order, among whom was Blessed Adrian Fortescue, martyred under Henry VIII.

After finishing this work Mattia Preti lived another 33 years in Malta making brief visits to his birth place and other parts of the mainland. He was enormously active and productive, not only enriching several of Malta's finest churches but also sending to Italy a stream of his best works on canvas. When of advanced age, Preti was wounded by his barber on a scar over his right cheek which "festered into gangrene" causing two years of agony before he succumbed on 3 January 1699. In his will he bequeathed the proceeds from many of his paintings to the poor, towards whom he had always been bounteous. He was buried with due pomp opposite the sacristy of St John's under a tombstone (fig 1 ) which reads:

Hic jacet magnum picturae decus Commend Fr Mathias Preti

Qui post summos honores, penicillo comparatos Romae, Venetiis, Neapoli

Sub auspiciis Em M M De Redin Melitam venit ubi ab Ordine Hieros: encomiis elatus

Ac inter Equites V L Italiae ex Gratia adlectus

Hanc Ecclesiam singulari pictura exornavit

Severioris mox pietatis studio incensus ingentem pecuniam tabulis quaesitam erogavit in pauperes

relicto pictoribus exemplo

Quo discerent pingere aeternitate

Ad qua evolavit nonagenario minor quatuor annis Tertio Non: Ianuari 1699

Frate Camillus Albertini Prior Baruli

Amico desideratissimo hoc monument: posuit.

It is such tombstones that entirely cover the floor of St John's. Most are much more ornate and commemorate "as in a marble edition of the Almanach de Gotha" the scions of the most noble families of all Europe: warriors, seamen, statesmen, and prelates. They are both an attraction and a distraction during services in St John's.

\section{Preti exhumed}

To mark the tercentenary of Mattia Preti's coming to Malta, in December 1962 the civic authorities of his native town of Taverna donated in the name of Societa' Artistica Mattia Preti a casket of oak and chestnut from the Calabrian forest of Sila, desiring that the remains of the painter should be deposited in it. Accordingly the Cathedral chapter of St John's appointed a commission of 10 people of whom I, as professor of anatomy at the Royal University of Malta, was one to exhume and report on the mortal remains of Mattia Preti. This we duly effected on 11 December at 800 am, and our report was duly delivered and sworn before the Notary to Government.

The main findings of our brief examination were that under Preti's tombstone we found a skeleton with hardly any remnants of a coffin or cerements; the bones were regularly and symmetrically disposed, which would indicate that they were not displaced after burial; many bones were fragmented and brittle, especially some'vertebrae and the facial bones, but all the bones of a complete skeleton were accounted for; the skeleton was that of a man of advanced age (certainly over 60 ) with no evident pathological features except for some degree of osteoarthrosis; 
anthropometric formulae applied to the long bones of the lower limbs indicated a height in life of $170 \mathrm{~cm}$. Photographs were taken of the bones in situ and then correctly disposed on tables for examination (fig 2), and the remains were reverently deposited in the new casket from Taverna, which was re-interred at the original site after a solemn High Mass "de requie" on Saturday 15 December 1962.

\section{Exhumations in history}

Exhumations do not feature in most doctors' experience, even in the rather gruesome circumstances of forensic investigation, still less under the more fascinating aspect of historical research. As examples of historical exhumations I recall "An Account of what appeared On Opening the Coffin of KING CHARLES THE FIRST, in the vault of King Henry the Eight, in St George's Chapel at Windsor, on the First of April
MDCCCXIII by Sir Henry Halford, Bart, FRS and FAS, Physician to the King and the Prince Regent" (published in London in 1813). Rather more portentous must have been the exhumations and the searches for traces of arsenic poisoning performed on the remains of Napoleon. Piteous indeed was the finding in 1674 in the Tower of London of the wooden chest containing the presumed remains of the two Princes, sons of Edward IV, said to have been murdered by Richard Crookback. In 1933 these remains were examined by Professor William Wright for the Anatomical Society and the identification practically confirmed.

There was nothing sinister in my own experience with Mattia Preti, solemn and serious enough, but almost a joyous occasion through its artistic connotation. Nor do I remember being deterred by the imprecation on the tombstone of William Shakespeare "and curst be he y' moves my bones!"

\title{
Medical Nobels - stamp of genius
}

\author{
James M Dunlop
}

Many doctors take up stamp collecting and a major attraction is that you are instantly available to deal with an emergency as your hands are clean (1). The popular image of a stamp collector as an elderly gentleman seated at a table, magnifying glass in hand (2) as he pores over little bits of paper, is far from true. People of every age collect stamps and there are probably as many women as men. All governments produce postage stamps illustrating countless different topics for a variety of reasons, and because of the vast number of stamps issued annually it is impossible to collect them all. So it is wise to confine collecting to a chosen country or theme-topical or thematic collecting.

The subject depicted on the stamp is the attraction and the choice is legion. Favourites are birds (3), plants (4), flowers (5), animals (6), ships (7), space (8), famous paintings (9), etc. Even famous fictional detectives $(10)$ have appeared on stamps. My original theme was skulls $(11){ }^{1}$ This was later expanded to anatomical drawings (12), then well known children's stories (13), and more recently to the stamping out of infectious diseases $(14) .^{2}$

Collecting stamps portraying Nobel prize winners is a popular theme for collectors (15). The subject is clearly defined and not too extensive. But it is difficult to discover whether some winners have ever appeared on stamps let alone to track them down-particularly when a country with no apparent connection with a prize winner portrays them on one of its stamps. The hunt adds to the fun.

\section{Nobel and his prize}

Alfred Nobel (16), 1833-96, the Swedish industrialist, explosives chemist, and inventor, endowed his fortune to fund a foundation whose income was to be "distributed annually in the form of prizes to those who during the preceding year conferred the greatest benefit on mankind." The document outlined five fields of endeavour-physics, chemistry, physiology or medicine, literature, and peace. Nobel's will concluded with the admonition that the most worthy be rewarded "whether he be Scandinavian or not."

Nobel made his money originally by prospecting for oil in Baku, Russia, and later by manufacturing dynamite-he patented its manufacture in 1867.
Nobel chose the Karolinska Institute, which was founded by the Swedish doctor Jons Jacob Berzelius (17), 1779-1848, to award the prize for physiology or medicine. Berzelius is considered to be the founder of inorganic chemistry - in 1840 he isolated biliverdin which he mistook for chlorophyl. Previously he had discovered the elements cerium, selenium, and thorium (by 1880, 22 of the 68 elements then known had been discovered in Sweden), and he assigned the actual symbols that we still use for them today. In 1806 Berzelius wrote prophetically:

Of all the sciences contributing to medicine, chemistry is the primary one and apart from the general light it throws on the entire art of healing, it will soon give some of its branches a perfection such as one never could have anticipated.

The Nobel peace prize is awarded by the Norwegian parliament-Norway was united with Sweden when Nobel died-the physics and chemistry prizes by the Swedish Academy of Sciences (Berzelius was its secretary from 1818-48), and the literature prize by the Swedish Academy. As part of its tercentennial celebrations in 1968 the Bank of Sweden founded a prize for economics in Nobel's memory (18).

The first Nobel prizes were awarded in 1901 (19) and from 1961 to 1981 Sweden issued annually on 10 December - the anniversary of Nobel's death and celebrated as Nobel day in Sweden-stamps commemorating the prize winners of exactly 60 years before. Thereafter the annual commemorative stamp issues have been devoted to one aspect of the prizes as follows: 1982-nuclear physics; 1983-chemistry; 1984-physiology; 1985-literature; 1986-peace; 1987-astrophysics. Where possible each year the Nobel prizewinners are handed their prizes by the King of Sweden at a ceremony in Stockholm.

\section{First medical laureate}

Emil Adolph Von Behring, 1854-1917, the German bacteriologist, became the first Nobel laureate in medicine in 1901 for his work with antiserum treatment and discovery of antitoxins (20). A cowinner of the first Nobel peace prize was Henri Dunant, 1828-1910, the founder in 1864 of the Red Cross Organisation (21). He chose to reverse the colours
Correspondence to: Hull

Health Authority, Victoria

HU2 8TD. 